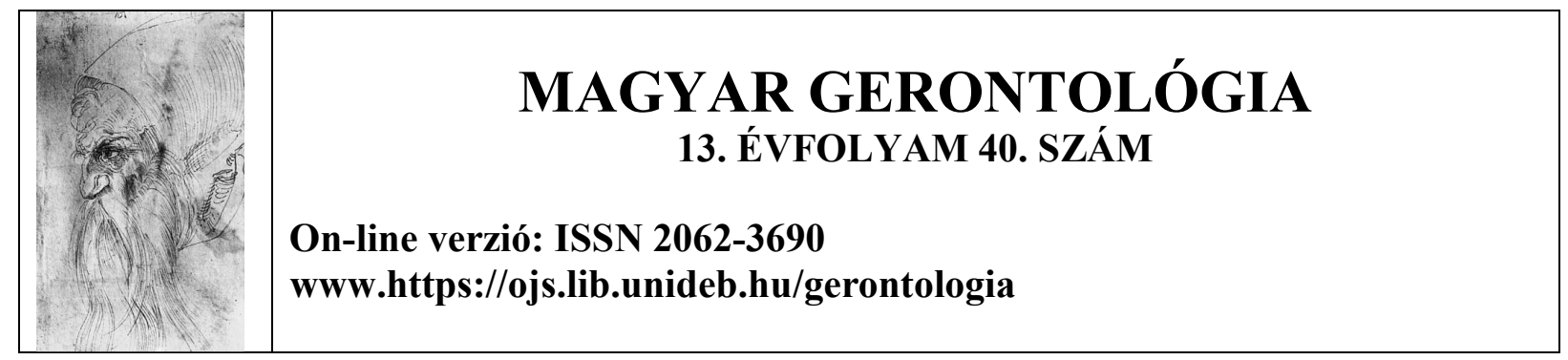

\title{
SURVEY ON UNVACCINATED ELDERLY PEOPLE DURING THE COVID-19 PANDEMIC. THE PATTERNS OF SANDWICH GENERATION AND THE AGE TRANSITION TO OLD AGE
}

\section{Adrienn Kaszás, Győző Pék, Balázs Őrsi}

University of Debrecen, Faculty of Humanities, Institute of Psychology

Key terms: Covid-19 pandemic; unvaccinated; anti- vaccinationists; attitudes to vaccination; sandwich generation

\begin{abstract}
The article focuses on the most important aspects of the first processing of the Hungarian results. The study involved 507 individuals: 117 men, 380 women, 2 individuals identified as 'other', and 8 respondents did not want to answer this question. The data processing shows that a large number of non-vaccinated people do not believe that they are at risk of developing COVID-19 virus. $42 \%$ of the non-vaccinated are very sure that the vaccine will not work, and $30.6 \%$ are afraid that they will become infected because of the vaccine. They do not feel safe after vaccinations and are afraid of the undiscovered consequences, and have more confidence in their natural immunity. $61.8 \%$ would not require the vaccine for themselves, nor in the future. $67.3 \%$ want to wait to see how vaccines work in other people. During processing, those with a specific anti-vaccinationist attitude could be identified and their profile was drawn. During the analysis, important aspects were identified for the development of effective communication strategies with the unvaccinated elderly. Highlighting the patterns of sandwich generation and the age transition to old age was also important aspect of analysis.
\end{abstract}




\section{Oltatlan idősek felmérése a COVID-19 pandémia folyamán. \\ A szendvics generáció és az áthajló korúak mintázata}

Kulcsszavak: Covid-19 pandémia; oltatlanok; oltásellenesek; attitüdök a vakcinációhoz; szendvics generáció

\section{Összegzés}

A tanulmány a magyar eredmények első feldolgozásának leglényegesebb aspektusainak bemutatására fókuszál. A vizsgálatban 507 személy, 117 férfi, 380 nő, 2 „egyéb”-ként azonosított ember vett részt, illetve 8 kitöltő nem szeretett volna válaszolni erre a kérdésre. $\mathrm{Az}$ adatfeldolgozásból kitünik, hogy az oltatlanok mintájában láthatóan nagyon sokan nem hiszik, hogy fennáll annak a veszélye, hogy megbetegednek a COVID-19 vírus miatt. A vizsgált oltatlanok 42\%-a nagyon biztos abban, hogy a vakcina nem fog müködni, 30.6\% fél, hogy az oltóanyag miatt meg fog fertőződni. Az oltások után nem érzik magukat biztonságban, valamint félnek annak még nem felfedezett következményeitől, illetve a természetes immunitásban jobban bíznak. 61.8\% nem igényelne vakcinát saját maga számára, a jövőben sem. 67.3\% szeretné megvárni hogy lássa, hogyan működnek az oltások más embereknél. A feldolgozás során azonosítani lehetett a kifejezetten oltásellenes attitüddel rendelkezőket, és megrajzolni profiljukat. Az elemzés során fontos szempontokat sikerült azonosítani az oltatlan idősek vonatkozásában, amelyek segítenek a velük való kommunikációs stratégia kialakításában. A szendvics generáció és az áthajló korúak mintázatának elemzése kiemelt figyelmet kapott.

\section{Introduction}

The Covid-19 virus has fundamentally changed our lives in Hungary since the beginning of 2020. At the end of our study, we are wrestling with the fourth wave of the pandemic, a mutation called 'omicron', a South African variant of the original virus. The omicron is the 16th letter of the Greek alphabet, and we know that this alphabet has 24 letters. While we don't know how many mutations we have to reckon with, it's certain: the epidemic is still going on. Surveys of unvaccinated people are needed because the more information we have about their mental state, vaccination attitudes, and demographic variables, the more likely we are to find the optimal communication tactics to motivate them to take the vaccine. We are deeply 
interested in the features of unvaccinated elderly people, because they are best- threatened during the pandemic due to their relatively poorer health conditions.

\subsection{Covid-19 pandemic and the media}

At the time of the article's birth the pandemic latest B.1.1.529 variant, named Omicron is becoming increasingly the most virulent. On 26 November 2021, WHO warned on the basis of increasing evidence that Omicron has several mutations, spreads very easily, more virulent than the previous variants, and probably would generate new waves of the Covid-19 pandemic. The news of current foreign media - due to the one important aspect of the globalization - are appearing abruptly and continuously. For example, the previously quoted statement of the WHO appeared immediately in the Hungarian online media (MTI, 2021; Szepesi, 2021).

If we look at the interfaces of online media available today, we can see the tension between the often contradictory expert statements.

In early 2022, optimistic and pessimistic forecasts alternate regarding the course, spread, and consequences of the Covid-19 pandemic. Official bodies provide citizens with ever-changing regulations, ordinances and recommendations that become widely available in different segments of the media.

The professional controversy over the taking of vaccines, the extension of precautionary measures, their updating and the need for them sooner or later became political, and this made it even more difficult for people receiving news to form a relatively stable position, to make decisions and to act.

Slogans like 'my body is my castle', which are popular among many anti-vaccinationists reinforce individualistic feelings and positions, often provoking defiant resistance and mistrust in 'suspicious' official resolutions and actions. Conspiracy theories are gaining ground and social media is also an excellent medium for their rapid spread. In addition, of course, media is able to strengthen and disseminate a more sober, more reasonable vaccination propensity. The Ipsos Global Reputation Centre concluded (Philips, 2022), that according to recent data of the Ipsos Global Trustworthiness Monitor, there is no indication to pose that trust was in 'crisis'. Otherwise trust may have been low for many organizations, sectors, or professions, there is slight proof that this had markedly changed. The report has reinforced that confidence in politician leader and the media is little, but that has hardly changed in the last decades and has not changed much over the last three years. The Covid-19 pandemic has effected the whole society worldwide in advance could not to indicate. But it has not yet had a significant impact 
on how much the people worldwide entrust the institutions, politicians and sectors with which they interact. The Hungarian online media also reacted to the report, in some cases with somewhat excessive journalistic presentation (Borsi, 2022). Changes in attitudes towards antivaccinationists and unvaccinated people can be well monitored in the media. The reaction of the public is also becoming more and more impatient with the emergence of another wave of the epidemic. With regard to the unvaccinated, the source of the information on the pandemic is of paramount importance. For this reason, it is important to map their media preferences in this regard.

The group of unvaccinated people - who have not received any vaccines against Covid-19 includes the ones with definite anti-vaccine attitude, who are showing a markedly stronger counter-commitment towards using the vaccines. An important and to be answered question is what attitudes, experiences, or perhaps solid systems of views and ideologies fuel the development and consolidation of vaccination resistance. In our research, partly related to the previous considerations, we considered it important to map vaccination attitudes and propensity, as well as to assess political orientation.

\subsection{Other significant sources of information}

We have to take into consideration that other sources represent significant influence on individuals who are at risk of infection. In this regard it is worth studying - in addition to the various segments of the media - such sources as family members, partners, friends, organizations, governmental communications, opinion of religious leaders and medical professionals.

\section{Methods}

We performed a comparative study using our questionnaire, focusing on the psychological and demographic aspects of the Hungarian unvaccinated people during the pandemic. The data collection with survey method lasted from 27 August to 13 October 2021. Participants were above 18 years of age who have not yet been vaccinated against the COVID-19 virus. We used the on-line questionnaire survey method. The research is not for political but for scientific purposes, and we hope that its results will contribute to a more professional management of the coronavirus epidemic. The Hungarian survey was conducted in collaboration with Polish, Slovenian and Romanian university researchers using a common test battery. The study 
involved 507 individuals: 117 men, 380 women, 2 individuals identified as 'other', and 8 respondents did not want to answer this question.

\subsection{The studied test dimensions and used questionnaires}

Well-being at the time of pandemic (happiness, health).

Depression, Anxiety and Stress Scale (DASS21). http://www2.psy.unsw.edu.au/dass/over.htm Vaccination Attitudes Examination Scale (VAX). https://www.fmhs.auckland.ac.nz

Sources of information about vaccination scale.

Religiosity level Demographics (metrics).

Proactive coping scale (PCI). https://estherg.info.yorku.ca/files/2014/09/pci.pdf

\subsection{Measures of statistical analysis}

We measured the different aspects of our study by using the following statistical analysis methods:

$\diamond \quad$ the stress levels of the age groups - Mann-Whitney U.

$\diamond \quad$ marital status $-\chi^{2}$ Tests.

$\diamond \quad$ anti-vaccination attitude in the elderly - Chi-squared test.

$\diamond \quad$ DASS-21 (depression, stress, anxiety) by age - Kruskal-Wallis test

$\diamond \quad$ proactive coping level by age - Kruskal-Wallis Test

$\diamond \quad$ belief in conspiracy theories - ANOVA

$\diamond \quad$ DASS-21 anxiety subscale by educational attainment - Kruskal-Wallis test

$\diamond \quad$ DASS-21 depression and stress subscale by age - Wilcoxon Rank Sum Test

$\diamond \quad$ VAX concerns about financial profiteering by age - Wilcoxon Rank Sum Test

\section{Results}

We would like to emphasize from the first processing of the data that a large number of unvaccinated people do not believe that they are at risk of getting the coronavirus. Furthermore, based on the results we could identify a definite anti-vaccination attitude group. The next data characterized the profile of the unvaccinated study group and help to make clear the underlying background, reasons of being unvaccinated. 


\subsection{Profile of unvaccinated people}

Almost half - $42 \%$ - of the unvaccinated people in our sample are very sure that the vaccine will not work, and almost a third $30.6 \%$ are afraid that they will become infected because of the vaccine. Furthermore, the majority do not usually feel safe after any vaccinations $(59.2 \%$ definitely disagree), moreover they are afraid of the undiscovered consequences $(68.6 \%$ definitely agree), and trust more in the safety of their natural immunity over the vaccine, regarding getting sick ( $45.5 \%$ definitely agree). Remarkable, that a decisive majority of them $-61.8 \%$ - definitely do not want a vaccine for themselves in the future. Also a decisive majority of the sample $-67.3 \%$ - are very cautious, they want to wait in order to see how vaccines affect other people. More than a half - 55.5\% - of the whole unvaccinated group says that their distrust of the health system is a main reason for their vaccination attitude. There is significant agreement with the statement that 'although most vaccines appear to be safe, there may be issues that have not yet been discovered' (58.3\% explicitly agree). Almost two third of them $75 \%$ - have concerns about vaccines safety.

Near half - $48.1 \%$ - of the unvaccinated explicitly agree that natural exposure to viruses and bacteria provides the safest protection. They also have less confidence that the government will ensure the safety and effectiveness of vaccination (76.7\% say this is a main reason).

$42.5 \%$ of the whole sample have already been infected and more than a half of them - $55.9 \%$ are not at all worried about SARS-CoV-2.

\subsection{Profile of anti-vaccinationists group}

Of the 507 individuals in the study, 422 were specifically anti-vaccinationists ('anti- group') representing 82 percent of the participants. This relatively high number is also due to the fact that we intentionally searched during the sampling for those, who are opposed vaccination. In addition to those described above, the group of definitely anti-vaccinationists has significantly less trust in the health care system, compared with the remaining half of the sample. The anti-group is also significantly more concerned about possible side effects $(84.3 \%$ say it is a main reason).

Members of the anti-group are significantly less likely to agree that they can rely on vaccines to stop serious infectious diseases (52.3\% of the unvaccinated strongly disagree). They also found the period of restrictions significantly more difficult (34\% of the unvaccinated found it fairly difficult, $15 \%$ found it very difficult) (Mann-Whitney U test: $\mathrm{p}=0.005$ ). 


\subsection{Significant differences between the anti-group and the remaining part of unvaccinated people are the next:}

Members of anti-group:

$\diamond \quad$ agree to a significant extent that being exposed to diseases naturally is safer for the immune system than being exposed through vaccination (Mann-Whitney $U$ test: $p<.001$ )

$\diamond \quad$ a significant part of the group is more concerned about the future unknown effects of the vaccines (Mann-Whitney $U$ test: $p<.001$ )

$\diamond \quad$ have significantly less trust in the health care system (Mann-Whitney U test: $p<.001$ )

$\diamond \quad$ agree to a significant extent that 'although most vaccines appear to be safe, there may be problems that we have not yet discovered' (Mann-Whitney U test: $p<.001$ )

$\diamond \quad$ are significantly more concerned about the safety of the vaccination (Mann-Whitney U test: $\mathrm{p}<.001)$

$\diamond \quad$ are significantly more concerned about possible side effects (Mann-Whitney U test: $\mathrm{p}=0.008)$

$\diamond \quad$ feel significantly less protected after vaccinations (Mann-Whitney $U$ test: $p<.001$ )

$\diamond \quad$ agree to a significant extent that natural exposure to viruses and germs gives the safest protection (Mann-Whitney $\mathrm{U}$ test: $\mathrm{p}<.001$ )

$\diamond \quad$ are significantly less confident that the government will ensure the safety of vaccination (Mann-Whitney U test: $\mathrm{p}<.001$ )

$\diamond \quad$ agree significantly less that they could rely on vaccines to stop serious infectious diseases (Mann-Whitney U test: $\mathrm{p}<.001$ )

\subsection{Age-related characteristic}

We have analyzed the differences between younger and older age subsamples and among younger-bending-older age subsamples. We found significant differences between young and old (below and over 65 years) age groups at these items:

$\diamond \quad$ 'I'm worried about possible side effects' The younger ones more....

$\diamond \quad$ 'I feel protected after vaccinations' The older ones feel more protected....

$\diamond \quad$ 'There are many important things happening in the world that the public is never informed about' The younger ones agree more....

In terms of political stance, the median was 4.00, young people tended toward the middle right (3.50) and older people tended toward the middle left (4.35). 
In each groups above the age 50, the number of married people was significantly higher than any other marital status type ( $\chi^{2}$ Tests $\mathrm{p}<.001$ ), and between $50-55$ and $56-60$, cohabitation was also relatively more common, as well as divorce.

Demographic features of the whole sample: $34.2 \%$ live in big cities, $35.8 \%$ in small towns, $21.3 \%$ in villages (other respondents live in suburbs or on farms).

There was no significant difference in the distribution of age groups 50-55, 56-60, 61-65, 66$70,70+$ in terms of anti-vaccination attitude in the elderly, measured by Chi-squared test.

The studied unvaccinated - including the subsample of elderly (above age of 65) - who had already been infected reported significantly higher levels of stress (Mann-Whitney $U \mathrm{p}<.001$ ). The younger age group (under 50) reached a near-significantly higher depression level compared to the 56-60 year olds $(\mathrm{p}=0.053)$. The level of depression was higher in the 50-55 years age group (median: 8) than in all other groups, and compared to the 56-60 years age group (median: 1$)$ at a significant level ( $\mathrm{p}=0.009)$ (Figure 1.).

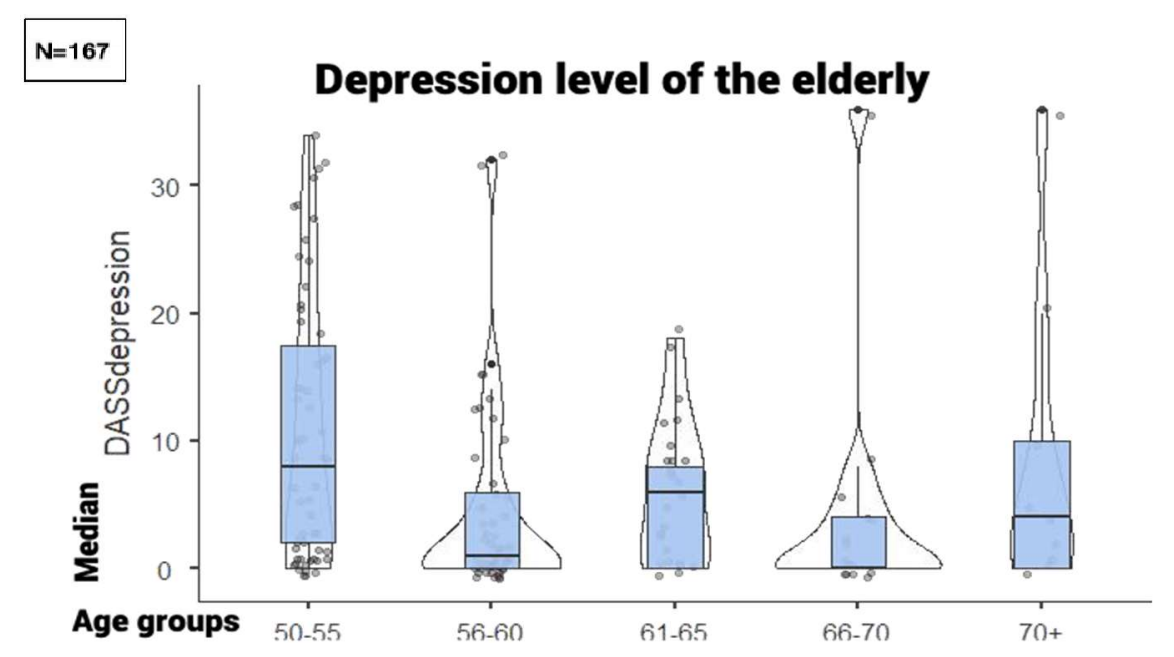

Figure 1. - Depression level of the elderly: median and distribution of the

DASS-21depression subscale by age groups

The younger age group (under 50) reached a significantly higher stress level compared to the 56-60 year olds ( $\mathrm{p}=0.029)$. Stress levels in the 50-55 year age group (median: 14$)$ were higher than in all other groups, and compared to age group 56-60 years at a significant level $(p=0.003$, median: 7) (Figure 2.). 


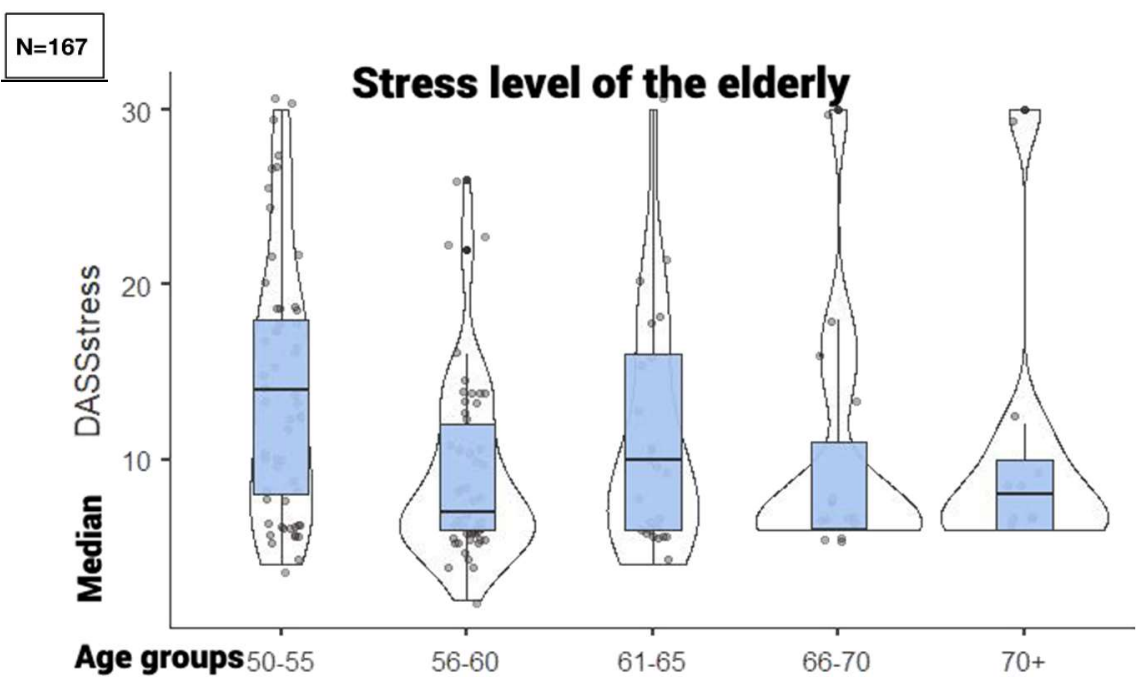

Figure 2. - Stress level of the elderly: median and distribution of the DASS-21 stress subscaleby age groups

ANOVA has also confirmed that the rate of belief in conspiracy theories begins to decline sharply at around age 45 - this declining transition lasts until between ages 45 and 55, and then stabilizes above age 55 at a lower level $(\mathrm{p}<.001)$. No significant difference was found between the younger group (below 45) and the middle aged group (45-55) but the elderly group (over $55)$ achieved a significantly lower value compared to both the middle aged $(p=0.019)$ and the younger group $(\mathrm{p}<.001)$ (Figure 3.).

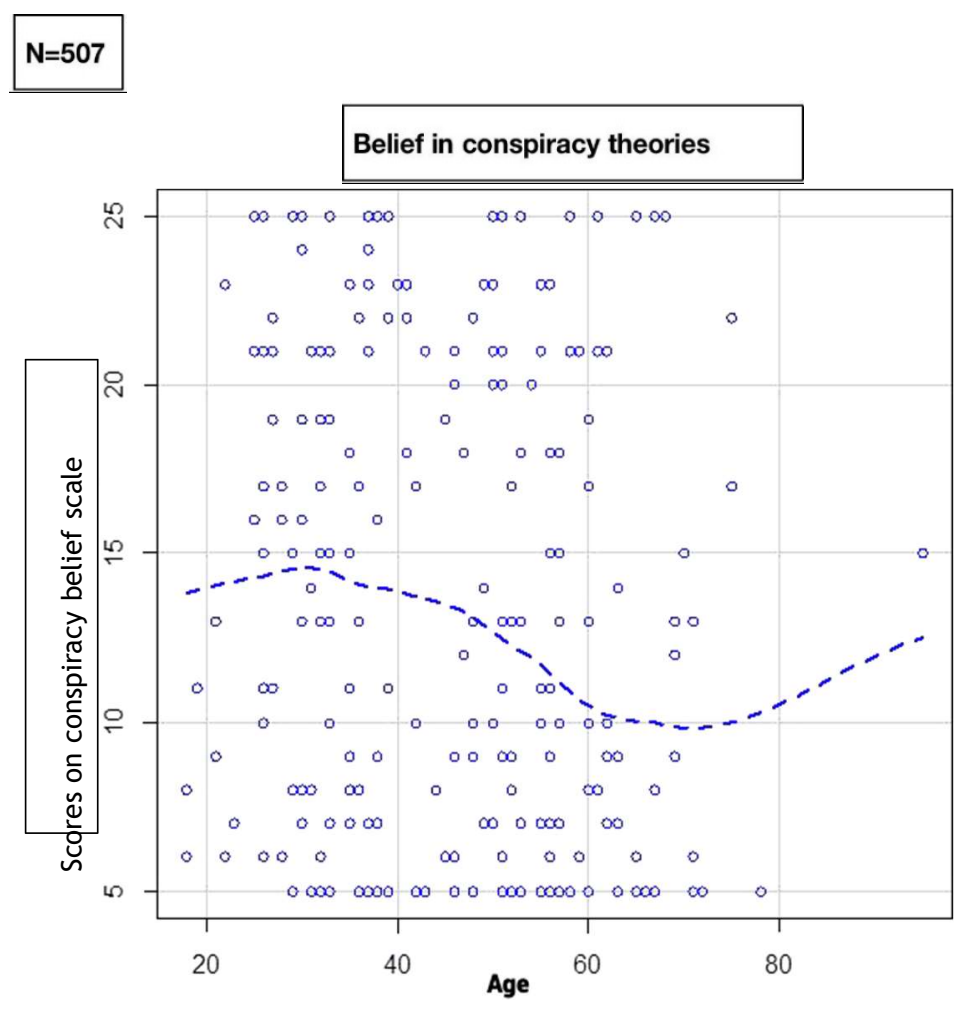

Figure 3. - Belief in conspiracy theories by age 
Proactive coping level for age 35-50 was significantly higher than for the other older (above 50) $(\mathrm{p}=0.030)$ or younger (below 35$)(\mathrm{p}<.001)$ age groups, performed the Kruskal-Wallis Test (Figure 4.).

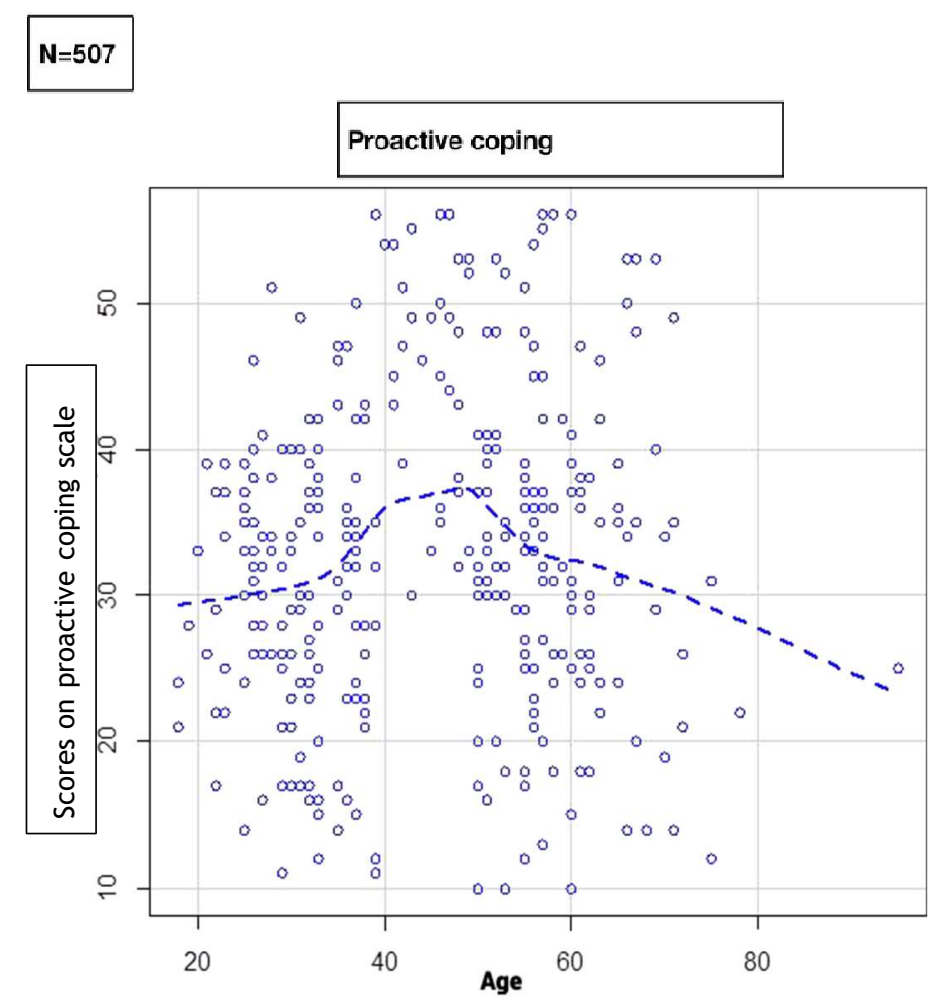

Figure 4. - Proactive coping by age

The DASS-2I anxiety subscale was examıned by educational attainment using the KruskalWallis test, where the p-value was 0.04677 . Primary school graduates were in the moderate range in terms of their level of anxiety, compared to the normal median for respondents in the other categories, the difference is significant.

Responses to the DASS-21 stress subscale were also subjected to statistical analysis from an age perspective (age cut off: 65 years); the Wilcoxon rank test reached a p-value of 0.00642 , measuring a significantly higher level of stress in the younger age group (Figure 5.). 


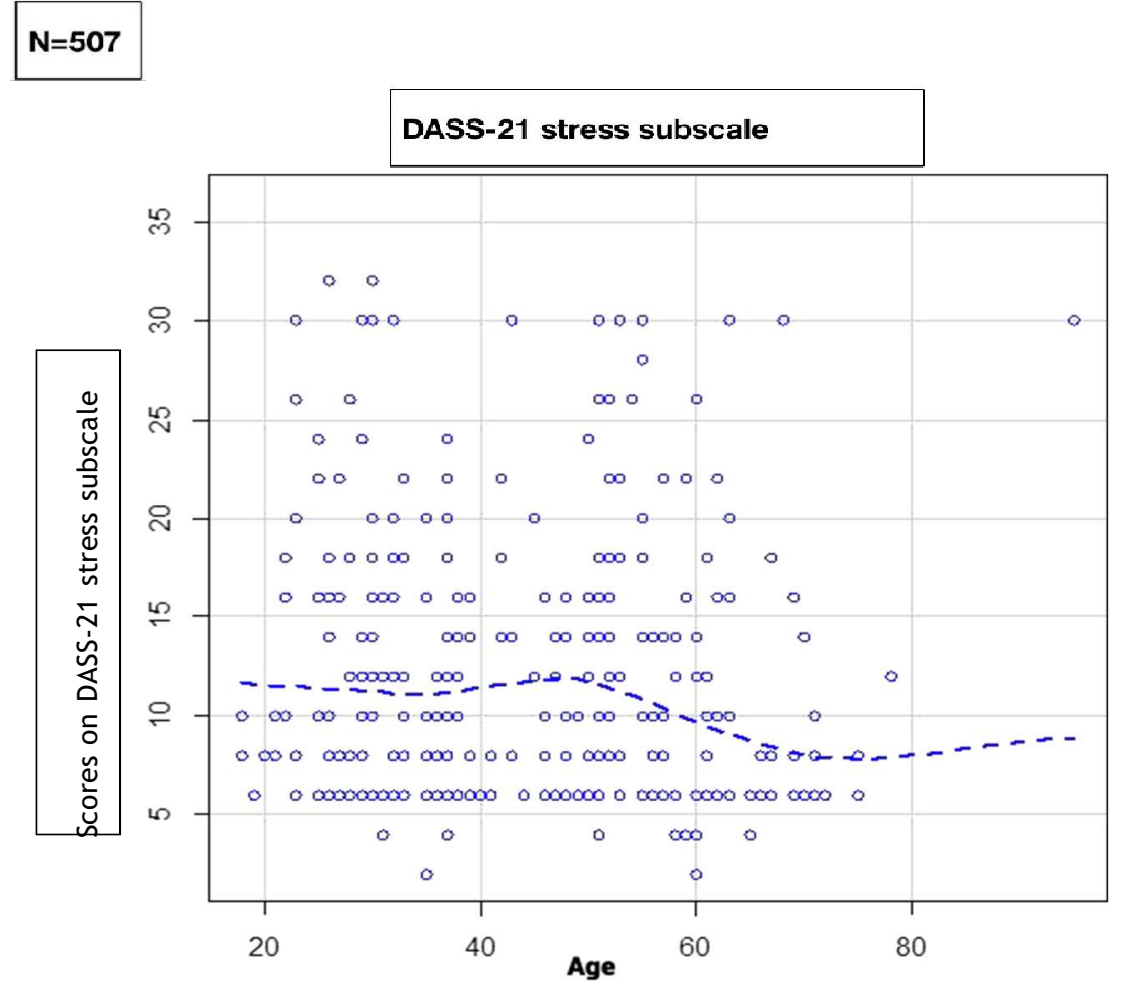

Figure 5. - DASS-21 stress subscale by age

The DASS-21 depression subscale was analyzed from an age aspect using the Wilcoxon Rank Sum Test, where $\mathrm{p}$ was 0.04369 . The depression value in the younger age group (under 65) reached a median of 4 , which is twice that of the elderly (over 65) (Figure 6.).

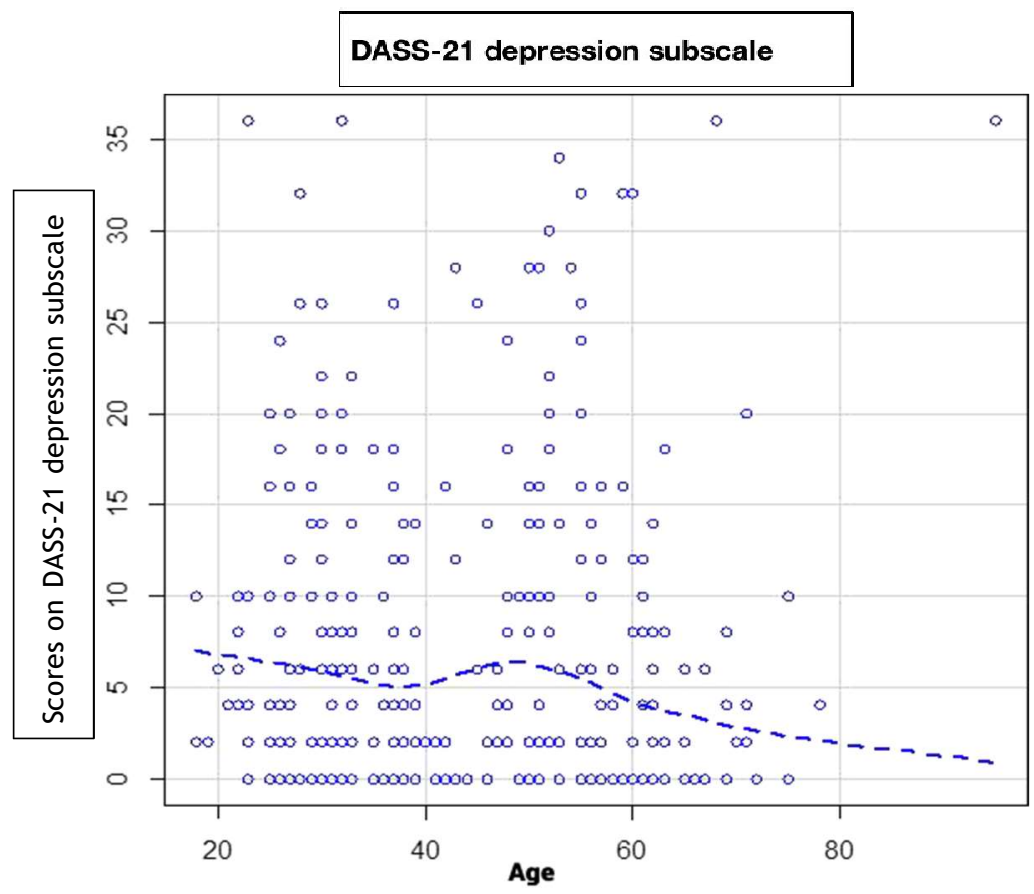

Figure 6. - DASS-21 depression subscale by age 
On the concerns about financial profiteering subscale in the VAX Scale, seniors (above age 65 ) reached significantly higher scores (Wilcoxon rank test $p=0.008416$ ) (Figure 7.).

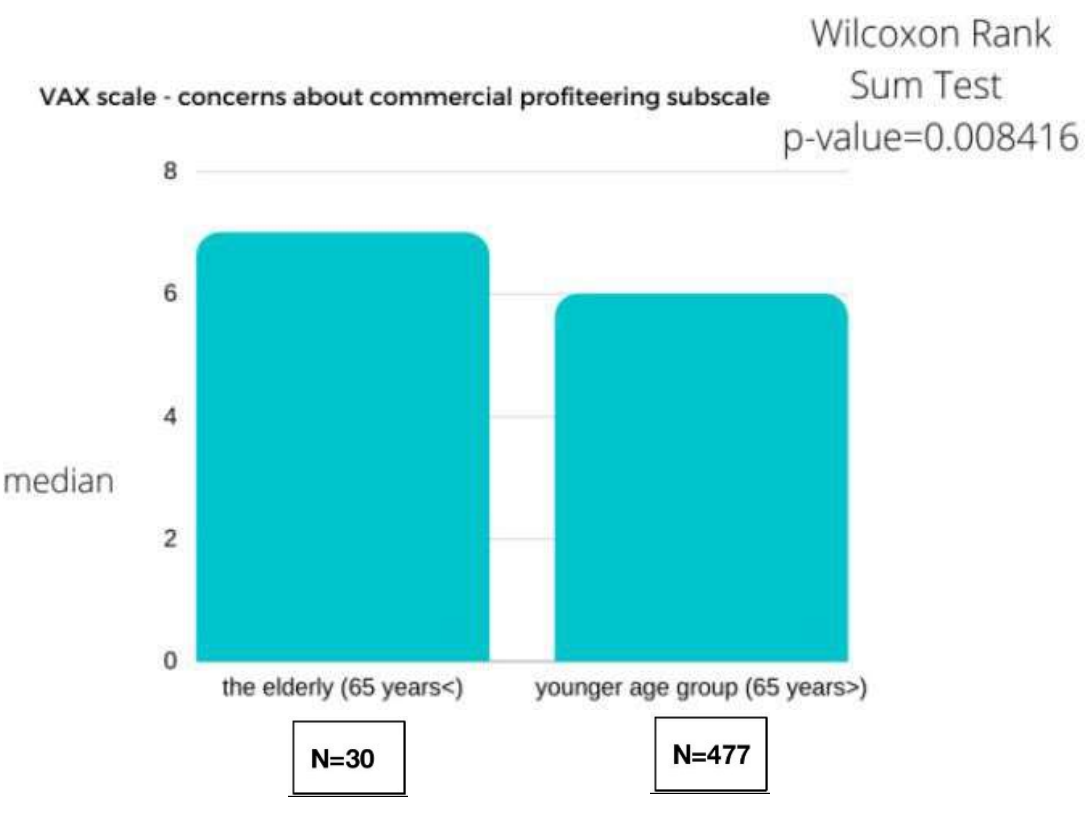

Figure 7. - VAX scale - concerns about commercial profiteering subscale by age

In addition to previously presented we found no significant difference in other aspects of age distribution. No causality was found for any other subscales, and the variance of the DASS-21 subscales is not explained by any other variables (Figure 7.).

\section{Discussion}

In the case of stress, according to the results, it is clear that the 50-55 and 55-60 age groups are at risk compared to younger people, and above 60 the stress and anxiety fall even below the level of young people. Thus, in the whole study sample, the levels of stress and depression in the 50-55 age group were found to be significantly higher than in the other older or younger elderly age groups. Actually, the life section between 50-60 years represents the age of transition to old age. In parallel the sandwich generation refers to middle-aged individuals who are constrained to support concurrently aging parents and growing children and these mainly occurs at adults ages from 40 till 59 (Parker and Patten, 2013). Comparing all these data we can conclude that members of the 50-55 age group who have been involved are in increasing danger during the Covid-19 pandemic - at the same time there is the challenging transition process, and they also bear the burdens of the sandwich generation.

From the point of view of the sandwich generation the assumption should be considered that the perceived mental load in adults approaching or entering the age of transition is higher and 
their mood life is worse. The 'normative' burdens arising from their generational situation can play a role in this, especially tasks such as ensuring the standard of living, family management, caring for children and parallel their aging parents. At the same time, we can count on the negative changes caused by the pandemic, which can range from an existential threat temporary or permanent job loss - through frustrations caused by restrictions to a constant fear of Covid-19 virus infection. The members of this age group are economically active, so the burden of maintaining of their own and currently of their family members' lives is heavier on them than on retirees and the elderly. The fact that the growing burden is likely to be more difficult to bear may also be due to the fact that they are generally in poorer health compared to the younger age groups, their bearing capacity is lower, and the loss of their jobs or financial resources may be more precarious due to the pandemic.

Studying the characteristics of the sandwich generation at the intersection of some international research, we can see that results relating to the risk of stress still exist as effect of uncontrollable stressors among the members of this age group. Isolation, high workload, economic situation, and the pandemic itself is causing discomfort that leads to stress (Putro, S. S., \& Riyanto, S., 2020).

A study during the COVID-19 pandemic aimed to examine the associations between family care, economic stress, and depressive symptoms among Chinese adults in urban and rural areas. Research results showed that care for both the elderly and younger ones was associated with significantly higher depressive symptoms compared with non-caregivers, and similar results were found in urban areas. In addition, economic stress reinforced the effect of family care needs on depressive symptoms in sandwich generation caregivers caring for both the elderly and children (Liu, C. et al., 2021). A convenience sample $(\mathrm{N}=77)$ of those belonging to the sandwich generation reported significantly more burden since the onset of the Covid-19 pandemic when compared to pre-pandemic burden in the U.S. The unprecedented, ongoing disruption, fear of death, and the stressors that come with it make the Covid-19 pandemic an enormous burden (Archer, J., et al., 2021).

The personal and financial sacrifices made by members of the sandwich generation have been in the focus of the media (Anderson 1999; Immen 2004; Kleiman 2002, as cited in Williams, C. 2004). However, some analysts have indicated that the sandwich generation is small, and the negative consequences are overemphasized (Fredriksen and Scharlach 1999, as cited in Williams, C. 2004). Others believe that caring for the senior by family members is better 
defined as 'helping' and that intensive care is very limited (Rosenthal and Stone 1999, as cited in Williams, C. 2004).

When we compared the results of those over 65 in our sample with those of younger age groups - below 65- , we found that over 65 their levels of stress and depression were both significantly lower. With older age the growing number of age-related chronic diseases in any case means an increased health risk, and also the course of the pandemic is more severe in them, with a higher need for care and more frequent mortality. Nevertheless, two basic aspects of psychic life, perceived stress and depression, appear to be more favourable in the sample of people over 65 years of age. It can be assumed that the relative balance resulting from their more economically inactive status plays a role in this, that even if their income is lower, it is more continuous and stable due to their pensions. They are in a better mental state according to the perceived stress and depression than the younger ones, despite the fact that information conveyed by the media also marks their generation as more vulnerable during the pandemic.

Our results help to understand, why the unvaccinated people haven't been immunized. What resources may have helped them specifically in these health beliefs. Presumably they formed their beliefs in spite of or against of information obtained from these very sources. The vast majority or a significant proportion of the unvaccinated people are suspicious of vaccines or attribute them harmful or unexpected effects. Anti-vaccination attitude can be linked, among other things, to the fact that nearly half of the sample clearly trusts in their natural protection over vaccines, regarding diseases. At the same time, the vast majority of them are taking a waitand-see attitude, waiting for more information on the effectiveness of vaccines on others.

Members of the clearly anti-vaccinationist group are more distrustful towards the health care system than the other unvaccinated people, and for more than half of them this is the ground for their opposition to vaccines. Most of them fear that vaccines may have hitherto unknown adverse effects, or have even greater fear of possible side effects. Compared to the other unvaccinated, a slightly higher proportion believe that natural exposure to viruses and bacteria provides the most reliable protection, while the role of vaccines in controlling infections is underestimated by the anti-vaccinationists. Their reluctance to get vaccinated may also be heightened by their distrust of the government, which is reflected in the vast majority, twothirds of them. They are experiencing greater frustration while being quarantined during the pandemic, and also because of the other austerity measures. In the group of unvaccinated, the subgroup of clearly anti-vaccinationists has partly common characteristics, their profile shows a similar pattern 


\section{Conclusions}

Along with the attitudes of unvaccinated and anti-vaccinationists and their beliefs about health, we can list the points and views that can form the attack points of a persuasive strategy. Thus, a plastically, clearly defined profile can serve as a basis for provoking change that can facilitate a more favourable shift towards vaccine propensity. Therefore, the results provide the possibility to serve important aspects for the communication strategies with unvaccinated elderly.

In Hungary, too, we can monitor the change in the acceptance of natural protection resulting from the transmission of the infection. This is a change in the status and scope of vaccination and coronavirus protection certificates. In Hungary, the protection of those who have been infected will be officially terminated from 15 February 2022, the protection certificate will expire and instead only the vaccination certificate proving the appropriate vaccination will be valid and desirable.

In international practice, proof of protection has been mostly accepted so far and has been equivalent to a vaccination certificate. One of the exceptions to this is Australia, where it is no longer possible to enter without a vaccination card. We learned about this from the media in connection with the sensational case of Djokovic, who is currently the number one tennis star in the world. He did not have a vaccination certificate, but was infected with coronavirus, and that was not enough to qualify for the Australian Open - was deported and could not enter the country for three years.

Uncertainty can also be felt in the professional circles regarding answering the complex question of the extent to which antibodies formed as a result of natural infection protect against coronavirus infection compared to antibodies provoked by the vaccine. As more and more of the challenges posed by many mutations in coronavirus, the process of developing and administering different vaccines and assessing their effects change over relatively short time intervals, there are no clear epidemiological models to use.

As a result of the above, the aversions, avoidance behaviour and reservations of the unvaccinated and the anti-vaccinationists about vaccination are partly understandable, as they, like all of us, can feel themselves confused in the middle of a rapidly changing communication network defined by a number of conflicting information. It is being re-evaluated almost daily, shaping in a rapidly changing pandemic situation, what is what 'common sense' dictates and how and in what way it is worthwhile and necessary to perceive, think and behave in the turmoil of a pandemic. 
Among the limitations of our study, we have to underline that the sample is not representative due to snowball method of sampling. Women are overrepresented. Otherwise, the distribution of residence does match relatively well to the Hungarian pattern and the age distribution, too. The relatively higher number of the anti-vaccinationists is resulted from the special sampling arrangement, because we intentionally searched for those who are opposed to vaccination. Highlighting the patterns of the sandwich generation and the age transition to old age were also important aspects of the analysis. The members of sandwich generation - between 50-60 years - have increased risk of stress and depression as effects of uncontrollable stressors among them. They have deserved special attention and care during the pandemic.

The authors unanimously share the belief that vaccination is one of the main methods in the fight against Covid-19 virus.

\section{Literature}

Anderson, T. (1999): Taking a bite out of the sandwich generation. USA Today 128 no. 2654 (November): 18-19.

Archer, J., Reiboldt, W., Claver, M., \& Fay, J. (2021): Caregiving in Quarantine: Evaluating the Impact of the Covid-19 Pandemic on Adult Child Informal Caregivers of a Parent. Gerontology and Geriatric Medicine. https://doi.org/10.1177/2333721421990150

Borsi, G. (2022): A magyarok sem a kormányban sem a médiában nem bíznak.

BGT (2022): A magyarok sem a kormányban, sem a médiában nem bíznak. Index, 2022.01.22. elérhető: $\quad$ https://index.hu/belfold/2022/01/22/a-magyarok-sem-a-kormanyban-sem-amediaban-nem-biznak-meg/

Fredriksen, K., \& Scharlach, A. E. (1999): Employee family care responsibilities. Family Relations 48, no. 2 (April): 189-196.

Immen, W., (2004): Caught in the 'sandwich.' Globe and Mail. March 17. C1-2.

Kleiman, C. (2002): Sandwich generation needs support. The London Free Press, April 29. Business section.

Liu, C., Zhang, L., Ahmed, F., Shahid, M., Wang, X., Wang, Y., Wang, J., \& Guo, J. (2021): Family Care, Economic Stress, and Depressive Symptoms Among Chinese Adults During the COVID-19 Outbreak: Difference by Urban and Rural Areas. Frontiers in psychiatry, 12, 700493. https://doi.org/10.3389/fpsyt.2021.700493 
Parker, K. \& Patten, E. (2013): The Sandwich Generation. Rising Financial Burdens for Middle-Aged Americans. Pew Research Center. Report January 30. elérhetö: https://www.pewresearch.org/social-trends/2013/01/30/the-sandwich-generation/

Phillips, C. (2022): Global Trustworthiness Monitor. Is Trust in Crisis? Foreword. Trust in 2021. https://www.ipsos.com/sites/default/files/ct/news/documents/2022-01/Global$\underline{\text { Trustworthiness-Monitor-2021.pdf }}$

Putro, S. S., \& Riyanto, S. (2020): How Asian sandwich generation managing stress in telecommuting during Covid-19 pandemic. IJSRED, 3(3), 485-92.

Rosenthal, Carolyn J. \& Leroy O. Stone. (1999): How much help is exchanged in families? Towards an understanding of discrepant research findings. SEDAP research paper no. 2. Program for Research on Social and Economic Dimensions of an Aging Population (SEDAP). Hamilton, Ont.: McMaster University.

Szepesi, A. (2021): Koronavírus: omikron az új mutáns neve, a WHO aggasztónak tartja. elérhető: $\quad$ https://www.napi.hu/nemzetkozi-gazdasag/koronavirus-fertozes-omikron-ujmutacio-who-aggasztonak-tartja.741048.html

WHO (2021): Home, News, Update on Omicron https://www.who.int/news/item/28-112021-update-on-omicron

\section{Authors:}

\section{Adrienn Kaszás, Győző Pék, Balázs Őrsi}

University of Debrecen, Faculty of Humanities, Institute of Psychology

\section{Correspondig author:}

\section{Adrienn Kaszás}

ORCID: 0000-0002-4744-0615

e-mail: adrienn.kaszas@icloud.com

University of Debrecen, Faculty of Humanities, Institute of Psychology 4032 Debrecen, Egyetem tér 1. 